\title{
Taeniosis-cysticercosis complex in individuals of a peasants' settlement (Teodoro Sampaio, Pontal of Paranapanema, SP, Brazil)
}

\author{
Luiz Euribel Prestes-Carneiro/ ${ }^{+}$, Selma de Bastos Zambeli de Freitas, \\ Sueli Cristina Schadeck Zago, Nadia Araújo Miguel, 0 swaldo Bill Primo, \\ Alberto Hiroshi Iha*, Noeli Maria Espíndola, Adelaide José Vaz
}

\begin{abstract}
Departamento de Imunologia, Universidade do Oeste Paulista, Rua José Bongiovani 700, 19050-900 Presidente Prudente, SP, Brasil *Departamento de Análises Clínicas e Toxicológicas, Faculdade de Ciências Farmacêuticas, Universidade de São Paulo, SP, Brasil
\end{abstract}

In order to evaluate the taeniosis-cysticercosis complex in a population of a peasants' settlement, located at

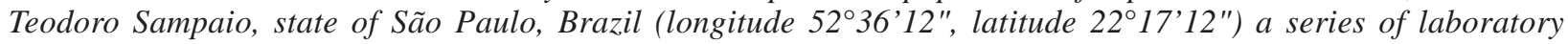
markers were determined. After signing an informed consent, participants answered a standardized questionnaire. To determine anti-Taenia solium cysticercus antibodies, the samples were tested by enzyme linked immunoabsorbent assay using 18-and 14-kDa antigen proteins from vesicular fluid of Taenia crassiceps (VF-Tcra). The reactive and inconclusive ELISA samples were tested by immunoblotting. Total IgE levels were determined by chemmiluminescence's assay and hemogram by flow cytometer flux counter. A total of 84 individuals, 5.9\% presented anti-T. solium cysticercus antibodies in ELISA and 3.6\% were strongly reactive in the 18/14 kDa immunoblotting confirmatory test. All of the individuals with positive antibodies showed elevated Total IgE levels. We conclude that the frequency of anti-T. solium cysticercus antibodies in this population is higher than other regions considered endemic in São Paulo. Thus, it is important to carry out surveys in Peasants' settlement areas with the objective of establishing public health measures for prevention and control of infectious diseases such as taeniosis-cysticercosis.

Key words: Taenia solium cysticercus antibodies - enzyme linked immunoabsorbent assay - immunoblot - IgE - Brazil

The taeniosis-cysticercosis complex is an important cause of morbidity and mortality, widespread not only in most underdeveloped countries, but also in industrialized ones (Raether \& Hanel 2003). There is strong evidence supporting the high prevalence of Taenia infection in humans from resource-poor areas, especially in rural areas with deficient sanitation, low hygienic standards, and unusual customs, such as consumption of raw pork (Phiri et al. 2003).

Taenia solium and Taenia saginata are two taenids of great economic and medical importance, causing bovine and porcine cysticercosis and taeniosis in humans. The encysted larva, known as cysticercus from $T$. saginata and T. solium are found in cattle and swine, respectively, and the adult tapeworm of $T$. saginata and T. solium are found in man. The cycle is completed when eggs in proglottids shed from the human tapeworm are disseminated to the environment through feces, followed by the ingestion by cattle or swine, and then the viable cysts are eaten by man in undercooked beef (Lees et al. 2002). People are also infected by ingestion of $T$. solium or T. saginata eggs by contact with carriers or contaminated foods.

Financial support: Unoeste, Fapesp, CNPq

Corresponding author.: luiz@unoeste.br

Received 13 June 2005

Accepted 19 December 2005
Cysticercosis is an infection caused by cysticercus, the larval stage of Cestoda Family Taeniidae. Neurocysticercosis (NC), the nervous-system form of cysticercosis is caused by larvae of tapeworm T. solium (Carpio 2002).

In Brazil, several previous studies have shown that $\mathrm{NC}$ in humans is an important public-health problem; although, very few reports on the prevalence and distribution of porcine cysticercosis have been published (Sakai et al. 2001). In the state of São Paulo, the frequency of anti-T. solium cysticercus antibodies in humans was determined in few counties (Vaz et al. 1990, Bragazza et al. 2002). Nonetheless, studies about the prevalence of $T$. saginata infection in humans or the presence of $T$. saginata cysticercus in cattle are scarce (Ungar \& Germano 1992). Dias et al. (1991) found in 311 samples of stools of humans living in the state of São Paulo an occurrence of $0.5 \%$ in Taenia sp. eggs; of which 273 were identified as T. saginata proglottidis.

The ELISA screening test is commonly used for the serological diagnosis of cysticercosis, although it crossreacts with cestoda parasites such as Hymenolepis nana and Echinococcus granulosos (Garcia et al. 2003, Ishida et al. 2003). Low-molecular-weight glycoproteins obtained from $T$. solium by affinity chromatography, considerably improved the specificity of ELISA screening tests, but a large amount of antigens is required (Tsang et al. 1989). Recently, it has successfully been reported the use of low-molecular-weight peptides obtained from the vesicular fluid of $T$. crassiceps antigens (Tcra-VF) and $T$. crassiceps cysticercus glycoproteins (Tcra-GP and 
Tcra(18-14)-GP in ELISA and immunoblot assays (Bueno et al. 2000, Pardini et al. 2002, Ishida et al. 2003).

The Pontal of Paranapanema region is located in the west of the state of São Paulo and concentrates the highest number of "Landless Peasants' Settlements" of the country. The region is characterized by large raising cattle farmers, and in the last decades, the "Landless Peasants" population increased abruptly, and pressure on proper land resulted in a large number of "Landless Peasants' Settlements". They are coordinated by the "Landless Peasants' Movement" (Itesp 2004).

These settlements are usually settled on marginal lands or beside highways, near cattle raising areas and water sources. Poor living conditions and lack of sanitary infrastructure, characterized by the use of open areas and fields for defecation, represent an important source of environmental contamination, which in turn may establish the biologic life cycle of parasites such as Taenia sp.

In order to evaluate the Taeniase-cysticercosis complex in Pontal of Paranapanema region, we determined laboratory markers in individuals from Pe. Josimo Peasants' settlement, located in Teodoro Sampaio, São Paulo, Brazil.

\section{MATERIALS AND METHODS}

Study design - Pe. Josimo Settlement, located in Teodoro Sampaio county, in the west region of the state of São Paulo, Brazil (longitude 52 ${ }^{\circ} 36^{\prime} 12^{\prime \prime}$, latitude $22^{\circ} 17^{\prime} 12^{\prime \prime}$ ) is an area occupied by the "Landless Peasants' Movement" since 2000, and recently expropriated for land reform purposes by the Brazilian National Institute for Land, Settlement and Agrarian Reform (Incra). With a tropical climate, followed by a rainy season in the summer, the region has a dry weather in the winter with a sandy top-soil mostly meant for pasture and cattle raising, with temperatures ranging from $28^{\circ} \mathrm{C}$ to $36^{\circ} \mathrm{C}$ in the summer. Most of the individuals interviewed lived in the marginal land, in a camping of plastic huts from 2000 to 2003, when the whole-expropriated area (2290 he) was divided into 96 small areas coordinated by São Paulo's Land Institute (Itesp 2004). The specimens were collected from February to April 2004, among 84 (25.8\%) out of 325 inhabitants from Pe. Josimo Peasants' settlement that agreed with this research. The results were set out for Teodoro Sampaio's Municipal Health Department, and individuals with anti-T. solium cysticercus reactive on ELISA and confirmed by immunoblot were directed to a neurologist of Hospital Universitário "Domingos Leonardo Cerávolo", Presidente Prudente, SP. The protocol of this study was approved by the Ethical Committee of Universidade do Oeste Paulista (Unoeste) no. 001/04, Presidente Prudente, SP, Brazil.

Twenty serum samples from patients with $\mathrm{NC}$ were tested. These patients had NC diagnosis confirmed by imaging exam (CT and/or MRI), clinical and immunological data, and were obtained from patients being seen at the Medicine Faculty Hospital of the University of São Paulo, São Paulo, Brazil. The control group consisted of 194 serum samples from apparently healthy individuals.

Data collection - Data were collected using a standardized questionnaire that included age, gender, place of birth, educational level, source of water supply, sani- tary facilities, income, clinical manifestations compatible with neurocysticercosis, and raising of swine and cattle.

The blood was collected in Vacutainer tubes with and without EDTA as anticoagulant. Serum was separated by centrifugation and stored at $-20^{\circ} \mathrm{C}$ until use.

Antigen - The 18- and 14-kDa proteins from vesicular fluid of VF-Tcra purified with monoclonal antibody antiTcra (18/14-Tcra) were obtained as described by Espindola et al. (2005).

Enzyme linked immunoabsorbent assay (ELISA-18/ 14) - Anti-T. solium cysticercus were detected by ELISA assay, carried out as described by Bueno et al. (2000) with some modifications. The test was carried out using 18and 14-kDa proteins. Each well of 96-well ELISA polystyrene high binding plates (Costar Corning Inc., Cambridge, MA) was coated with $100 \mu \mathrm{l}$ of antigen $(0.5 \mu \mathrm{g} / \mathrm{ml})$ in 0.5 $\mathrm{M}$ carbonate-bicarbonate buffer ( $\mathrm{pH} 9.6)$ for $18 \mathrm{~h}$ in a humidified chamber at $4{ }^{\circ} \mathrm{C}$. The wells were blocked for $1 \mathrm{~h}$ with 5\% milk in phosphate-buffered saline (PBS; $0.01 \mathrm{M}$; $\mathrm{pH} 7.2 ; 0.0075 \mathrm{M} \mathrm{Na}_{2} \mathrm{HPO}_{4}, 0.025 \mathrm{M} \mathrm{NaH}_{2} \mathrm{PO}_{4}, 0.15 \mathrm{M}$ $\mathrm{NaCl}$ ) containing $0.05 \%$ Tween 20 (PBS/T), and then incubated for $1 \mathrm{~h}$ with serum samples diluted 1:50. Goat antihuman IgG peroxidase-conjugated (Biolab Diagnóstica S. A., Rio de Janeiro, Brazil) was added and plates were incubated for $1 \mathrm{~h}$. After each incubation step, the plates were washed using an automatic washer, with four cycles of saline $(0.15 \mathrm{M} \mathrm{NaCl})$ containing $0.05 \%$ Tween 20 . Orthophenylenediamine $(1 \mathrm{mg} / \mathrm{ml})$ and $\mathrm{H}_{2} \mathrm{O}_{2}(1 \mu \mathrm{l} / \mathrm{ml})$ diluted in $0.2 \mathrm{M}$ citrate buffer ( $\mathrm{pH}$ 5.0) were added (in the dark) as chromogenic substrate and plates were incubated for 20 $\min$. The reactions were stopped by adding $100 \mu 1$ of $2 \mathrm{M}$ $\mathrm{H}_{2} \mathrm{SO}_{4}$. Color intensity was quantified using an ELISA plate reader (Diagnostics Pasteur, Strasburg-Schiltigheim, France) at $492 \mathrm{~nm}$. All incubations were carried out at $37^{\circ} \mathrm{C}$.

Immunoblotting (WB-18/14) - The ELISA reactive samples were submitted to immunoblotting using 18/14Tcra proteins for the analysis of antibody specificity. The 18/14-Tcra proteins were separated by sodium duodecyl sulfate polyacrylamide gel electrophoresis (SDS-PAGE) following the method described by Laemmli (1970). The antigens were solubilized with sample buffer ( $0.01 \mathrm{M}$ Tris$\mathrm{HCl}$; pH 6.8, containing 2\% SDS, 5\% 2-mercaptoethanol, and $10 \%$ glycerol) at $100^{\circ} \mathrm{C}$ for $5 \mathrm{~min}$ and separated eletrophoretically in $15 \%$ polyacrilamide gel. The separated antigens were eletrophoretically transferred to a 0.22 $\mu \mathrm{m}$-pore-size membrane of polyvinylidene difluoride (Millipore Corp., Bedford, MA). The membranes were blocked by treatment with 5\% skimmed milk (Molico Skim milk, Nestlé, Araçatuba, SP, Brazil) in PBS for $2 \mathrm{~h}$, washed in PBS containing $0.05 \%$ Tween 20 (Merck, Schudart, Munich, Germany), and then incubated for $18 \mathrm{~h}$ at $4^{\circ} \mathrm{C}$ with sera diluted at 1:50, in $1 \%$ skimmed milk in PBS. After further PBS washes, strips were incubated for $1 \mathrm{~h}$ with goat anti-human-IgG-biotin/avidin-peroxidase (Sigma Chem. Co., St. Louis, MO) conjugate. After additional washes, 4-chloro-1-naphthol (Sigma) pre-dissolved in methanol (20\% of the volume) and then diluted to $0.05 \%$ with Tris-buffered saline $(0.01 \mathrm{M}$ Tris, $0.15 \mathrm{M} \mathrm{NaCl} \mathrm{pH}$ 
7.4) containining $0.06 \% \mathrm{H}_{2} \mathrm{O}_{2}$ was added as chromogenic substrate.

Total IgE levels - Total IgE was determined in sera samples using an automated chemmiluminescence assay (Immulite Diagnostic Products Corporation, Los Angeles, CA), according to the manufacturer's instructions.

Hemogram - The hemogram was undertaken by a flow cytometer flux counter (Pentra 80, Horiba Diagnostics, Montpellier, France), and the leukocyte differential counting was compared to direct microscopic observation in blood smears, taken as the reference method. Eosinophils counts were classified as proposed by William's (1991).

Coproparasitologic studies - The stools were collected and examined using Faust and Hoffmann, Pons and Janner methods, for detection of cysts, parasites or adult proglottidis (Pessoa \& Martins 1982).

Statistical analysis - Anti-T. solium cysticercus and IgE levels were compared using independent samples $\mathrm{t}$ test and chi-square $\left(\chi^{2}\right)$ and Fisher Exact Method were applied when indicated through the GraphPad Software (V3.0) (San Diego, CA). The level of statistical significance was $5 \%$.

\section{RESULTS}

Demographic, environmental and behavioral characteristics - From Pe. Josimo peasants' settlement inhabitants that participated in this survey, 38 (45.2\%) were female and $46(54.8 \%)$ were male. The population age distribution ranged from 6 to 71, of which 55 (65.5\%) were classified as adults and $29(34.5 \%)$ as children. Forty-two (50\%) of the individuals were born in São Paulo, 11 (13.1\%) were born in Paraná, and 33 (39.2\%) in other Brazilian states. Only $6(7.1 \%)$ had high school education and $10(11.9 \%)$ lacked elementary instruction. The majority $(77.3 \%)$ had completed primary school. The income varied from less than U\$ $100.00(91.6 \%)$ to about U\$ 170.00 (8.4\%) per month. Seventy-four individuals $(88 \%)$ had ground floor wells or "cacimbas", and 10 (11.9\%) used opened ground mines as water source. Seventy-eight individuals (92.8\%) have latrines located beside the houses and $6(7.1 \%)$ have neither toilet facilities nor latrines, and defecated outdoors. Twenty-one (25\%) had pig husbandry and 47 $(55.9 \%)$ domestic cattle. Among the interviewed individuals $24(28.6 \%)$ reported having headaches, and $10(11.9 \%)$ vertigo. None of them reported having convulsion or epilepsy.

ELISA-18/14 - The analysis of 20 serum samples from patients with confirmed NC showed sensitivity of $100 \%$ (Fig. 1). The normal serum samples from 194 healthy individuals presented cut-off borderline $\leq 0.350 \mathrm{~nm}$ and specificity of $99.5 \%$ (Fig. 1). In Pe. Josimo Settlement group, from 84 serum samples tested, 5 (5.9\%) samples presented cut-off $\geq 0.350 \mathrm{~nm}$ (Fig. 1).

Immunoblotting (WB-18/140) - From 5 (5.9\%) samples from Pe. Josimo settlement group that presented cut-off $\geq 0.350 \mathrm{~nm}$ in the ELISA-Tcra $3(3.6 \%)$ were strongly reactive in the IB-18/14 kDa (Fig. 2). Serum samples from controls with negative and positive ELISA results were ana- lyzed by IB-18/14, and found to be positive (see 1 to 3 in Fig. 2) and negative (see 4 and 5 in Fig. 2), respectively.

Total IgE - Seventy-eight (93.9\%) out of 83 serum samples showed Total IgE concentration higher than normal values (Fig. 3).

We found a positive association in total $\mathrm{IgE}$ levels and the anti-T. solium cysticercus antibodies $(* p<0.05)$, since $5(100 \%)$ of the samples that presented $\geq 0.350 \mathrm{~nm}$ cut-off showed elevated levels of IgE distributed as follow: mild $1(20 \%)$, moderate $3(60 \%)$, and severe $1(20 \%)$.

Hemogram - Of the 81 individuals submitted to hemogram counts $65(80.2 \%)$ showed isolated or associated eritrocyte/leukocyte disorder. Thirty individuals (37\%)

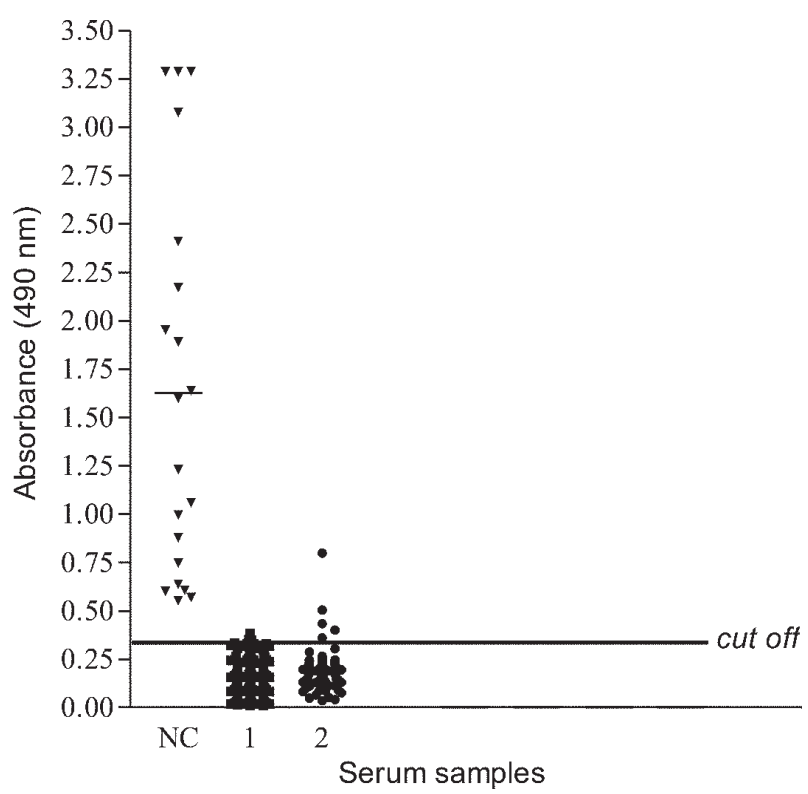

Fig. 1: enzyme linked immunoabsorbent assay results with vesicular fluid-Taenia crassiceps antigen (18/14-kDa proteins) purified with anti-VF-Tcra, of serum samples from patients with neurocysticercosis (NC), serum samples from apparently healthy individuals, (1) and serum samples from individuals of Pe. Josimo Peasants' settlement (2).

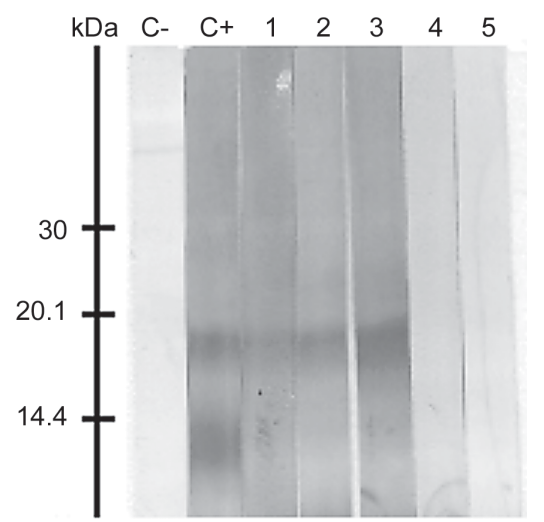

Fig. 2: results of immunoblotting using 18/14-Tcra antigen purified by anti-vesicular fluid-Taenia crassiceps monoclonal antibody with serum samples from apparently healthy individuals $(\mathrm{C}-)$; serum sample from patients with neurocysticercosis $(\mathrm{C}+)$; and serum samples from individuals of Pe. Josimo peasants' settlement $(1,2$, 3,4 , and 5). 
presented enhanced eosinophils counts distributed mainly in children: $0 \mid-10$ years of age $5(16.6 \%), 10 \mid-20,7(23.3 \%)$, and old people ranging from 50|-60, $6(20 \%)$, and 60 |- years of age $5(16.6 \%)$. We found a positive association in the whole studied population when correlating IgE levels with increased eosinophils counts $(* p=0.02)$ the mean \pm SEM of $\mathrm{IgE}$ levels in normal, mild and moderate eosinophils group was: $618.8 \pm 102.9 ; 922.5 \pm 121.3$; and $1671 \pm 322.5$, respectively (Fig. 3). However, it was not found association between anti-T. solium cysticercus antibodies and eosinophilia.

Coproparasitologic studies - Among 49 stools examined, Entamoeba coli cysts were present in $9(18.3 \%)$ and Giardia lamblia cysts in 3 (6.1\%) individuals.

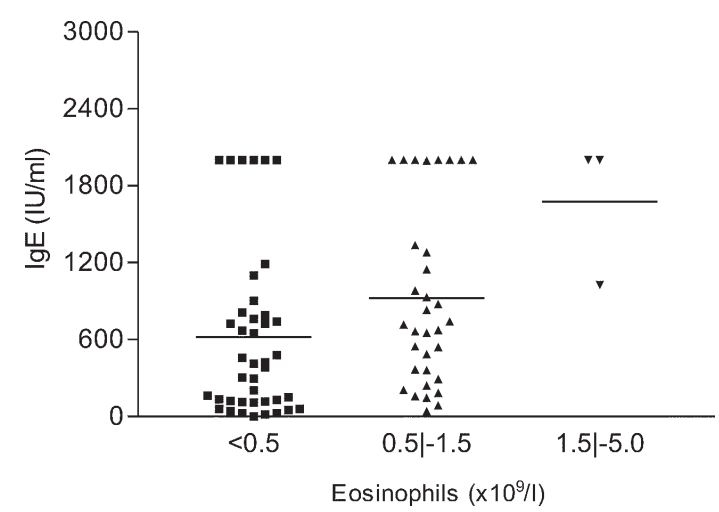

Fig. 3: correlation between IgE levels and eosinophils in individuals from Pe. Josimo settlement, Teodoro Sampaio, SP, Brazil. The eosinophils were classified in the hemogram as: normal $<0.5 \times 10^{9} /$ 1 ; mild $0.5 \mid-1.5 \times 10^{9} / 1$; moderate $1.5 \mid-5.0 \times 10^{9} / 1$ in 84 individuals. Total IgE levels were determined by chemiluminescence method in 83 serum samples and classified according to our own reference ranges as follows: normal $(<100 \mathrm{IU} / \mathrm{ml})$; mild $(100 \mid-300 \mathrm{IU} / \mathrm{ml})$; moderate $(300 \mid-1000 \mathrm{IU} / \mathrm{ml})$, and severe $(>1000 \mathrm{IU} / \mathrm{ml})$. Values $>$ $2000 \mathrm{IU} / \mathrm{ml}$ were considered over-flow $* p=0.02$.

\section{DISCUSSION}

The taeniosis-cysticercosis complex occurs mainly in less developed countries. T. solium is widespread through South America, India, and China, and may also be endemic in sub-Saharan Africa (Pal et al. 2000). T. saginata is the main cestoda found in Europe with $0.01-10 \%$ of prevalence, although it can reach a prevalence of 2-10\% in Afghanistan, Azerbaidjan, India, and Malaysia (Cabaret et al. 2002). It has a moderate prevalence in South American countries and $0.01 \%$ in Brazil. Nonetheless, the knowledge of the infection in cattle or humans is insufficient, due to the lack or inexactness of information (Sakai et al. 2001, Cabaret et al. 2002, Agapejev 2003).

In this study we found a frequency of $5.9 \%$ of anti- $T$. solium cysticercus antibodies detected by ELISA screening assay, carried out through a 18-14 kDa purified antigenic protein from VF-Tcra. The reactive ELISA samples were tested by immunoblotting as a confirmatory test, and $3.6 \%$ resulted immunoreactive to the immunodominant 18 - and $14 \mathrm{kDa}$ peptides. Individuals with specific anti- $T$. solium cysticercus antibodies were adults. Two of them came from Pontal of Paranapanema region and one from the northern of Paraná, an endemic region for cysticercosis (Lonardoni et al. 1996). It has been shown that lowmolecular mass peptides $(\leq 20 \mathrm{kDa})$ found in $T$. crassiceps are similar to $T$. solium antigens extracts, and considered specific for cysticercosis, improving the specificity of screening and confirmatory tests, especially in serum samples which cross-react with other cestoda antigens (Bueno et al. 2000, Pardini et al. 2002). ELISA tests showed sensibility of $100 \%$ in patients diagnosed with NC in our survey. The frequency of anti-T. solium cysticercus antibodies in the studied population is higher than those found by Bragazza et al. (2002), using a similar methodology in a population of Cássia dos Coqueiros (2.1\%), a rural area near Ribeirão Preto, São Paulo, also considered an endemic region for cysticercosis. Surveys by ELISA by Vaz et al. (1990) in a population from five counties of São Paulo, and Silveira-Lacerda et al. (2002) in blood donors from four cities in Minas Gerais found a frequency of anti-T. solium cysticercus antibodies of 2.3 and $5.6 \%$ respectively. Using indirect immunofluorescence assay, Lonardoni et al. (1996), in individuals of five counties from northern of Paraná, found a frequency of 3.2\%. However, in the studies reported above, the results were not confirmed by immunoblot, and some of the reactive samples could be false-positive results, since screening methods lack specificity (Tsang et al. 1989). In a recent literature review, seroepidemiological surveys in the South and Southeast region of Brazil, including São Paulo, showed $0.8 \%$ cysticercosis positivity for children, and $2.3 \%$ positivity in the general population (Agapejev 2003) .

Before land expropriation and distribution, most individuals of our studied population lived 2-3 years in a marginal land camping organized by the "Landless Peasants' Movement". As already mentioned, these campings are characterized by poor living conditions, deficient potable water supply and sanitary facilities, and could be a focus of taeniosis infection. Socioeconomic status is shown in scientific literature as being one of the key conditions to acquire most of the infections in parasitic diseases, including taeniosis and cysticercosis, especially in the tropical and subtropical world.

In animal models and clinical surveys, helminthic infections, such as taeniosis, are associated with eosinophilia and high levels of IgE, once they act together in the immune response against parasites (Gounni et al. 1994). Rodriguez-Sosa et al. (2004) demonstrated that mice infected with T. crassiceps displayed high levels of IgE and a Th2 immune response. Total and specific IgE were also found in serum samples and cerebrospinal fluid of patients with cysticercosis (Short et al. 1990, Bueno et al. 2000). Furthermore, Chavarria et al. (2005) showed increased levels of eosinophils in cerebrospinal fluid of patients with cysticercosis. Indeed, all of the individuals in our survey which resulted positive for anti-T. solium cysticercus antibodies showed elevated levels of IgE, although they were not correlated with eosinophilia. In the whole population studied, $93.9 \%$ of individuals presented an increase in total IgE concentration and a positive correlation with increased eosinophils counts (mild and moderate levels) was found ( $\left.{ }^{*} p=0.02\right)$. These data suggest 
that other antigens than helminthes infection are triggering this immune response.

There were few people infected with pathogenic cysts and none infected with helminthes among the surveyed participants. This low prevalence of intestinal parasites is in contrast with different studies carried out in rural areas and poor populations in Brazil and elsewhere (Kobayashi et al. 1995, Carvalho et al. 2002, Abd El Bagi et al. 2004). In a survey among "Landless Peasants Communities" in Rio Grande do Sul, De Carli et al. (1994) showed intestinal parasites infection prevalence of $42.4 \%$ in Charqueadas and $51 \%$ in Capela Santana, being that in the latter, $1.3 \%$ of individuals presented eggs of Taenia sp. too. The low prevalence of parasites in our studied population may be due to the medical assistance and treatment received by the community by the Family Health Program, with weekly medical visit to the settled Pe. Josimo Peasants Settlement (pers. commun.).

We conclude that the detection of anti-T. solium cysticercus antibodies in individuals of Pe. Josimo peasants' settlement is higher than other regions considered endemic in São Paulo. Besides, the increased levels of IgE and eosinophils could be an immune response to environmental antigens and should be investigated. Thus, it is important to carry out surveys in peasants' settlement areas with the objective of establishing public health measures for prevention and control of infectious diseases such as taeniosis-cysticercosis.

\section{ACKNOWLEDGMENTS}

To Sérgio Wilson Ferreira Chiari, Health Secretary of Teodoro Sampaio Municipality.

\section{REFERENCES}

Abd El Bagi ME, Sammak BM, Mohamed AE, Al Karawi MA, Al Shahed M, Al Thagafi MA 2004. Gastrointestinal parasite infestation. Eur Radiol 14: 116-131.

Agapejev S 2003. Clinical and epidemiological aspects of neurocysticercosis in Brazil: a critical approach. Arq Neuropsiquiatr 61: 822-828.

Bragazza LM, Vaz AJ, Passos AD, Takayanagui OM, Nakamura PM, Espindola NM, Pardini A, Bueno EC 2002. Frequency of serum anti-cysticercus antibodies in the population of a rural Brazilian community (Cassia dos Coqueiros, SP) determined by Elisa and immunoblotting using Taenia crassiceps antigens. Rev Inst Med Trop São Paulo 44: 7-12.

Bueno EC, Vaz AJ, Machado L, Livramento JA 2000. Total IgE detection in paired cerebrospinal fluid and serum samples from patients with neurocysticercosis. Rev Inst Med Trop São Paulo 42: 67-70.

Bueno EC, Vaz AJ, Machado LD, Livramento JA, Mielle SR 2000. Specific Taenia crassiceps and Taenia solium antigenic peptides for neurocysticercosis immunodiagnosis using serum samples. J Clin Microbiol 38: 146-51.

Cabaret J, Geerts S, Madeline M, Ballandonne C, Barbier D 2002. The use of urban sewage sludge on pastures: the cysticercosis threat. Vet Res 33: 575-597.

Carpio A 2002. Neurocysticercosis: an update. Lancet Infect Dis 2: 751-762.

Carvalho Odos S, Guerra HL, Campos YR, Caldeira RL,
Massara CL 2002. Prevalence of intestinal helminthes in three regions of Minas Gerais State. Rev Soc Bras Med Trop 35: 597-600.

Chavarria A, Fleury A, Garcia E, Marquez C, Fragoso G, Sciutto E 2005 Relationship between the clinical heterogeneity of neurocysticercosis and the immune inflammatory profiles Clin Immunol 116: 271-278.

De Carli GA, Spalding SM, Rott M, Ribeiro L, Chaves A, Silva AMC, Wendorgg A, Matos S, Pozza C 1994 Survey of intestinal parasites among rural communities living in Charqueadas and Capela de Santana in Rio Grande do Sul State. Rev Bras Anál Clin 26: 123-125.

Dias RM, da Silva MI, Mangini AC, Vellosa SA, Torres DM, da Silva RM, Vaz AJ 1991. Occurrence of Taenia sp. in the population seen at the Central Laboratory of the Adolfo Lutz Institute, São Paulo, SP, Brazil (1960/1989). Rev Inst Med Trop São Paulo 33: 147-151.

Espindola NM, Iha AH, Fernandes I, Takayanagui OM, Machado LR, Livramento JA, Mendes Maia AA, Peralta JM, Vaz AJ 2005. Cysticercosis immunodiagnosis using 18- and 14-kilodalton proteins from Taenia crassiceps cysticercus antigens obtained by immunoaffinity chromatography. J Clin Microbiol 43: 3178-3184.

Garcia HH, Gonzalez AE, Evans CA, Gilman RH 2003. Taenia solium cysticercosis. Lancet 362: 547-556.

Gounni AS, Lamkhioued B, Delaporte E, Dubost A, Kinet JP, Capron A Capron M 1994. The high-affinity IgE receptor on eosinophils: from allergy to parasites or from parasites to allergy? J Allergy Clin Immunol 94: 1214-1216.

Ishida MM, Rubinsky-Elefant G, Ferreira AW, Hoshino-Shimizu S, Vaz AJ 2003. Helminth antigens (Taenia solium, Taenia crassiceps, Toxocara canis, Schistosoma mansoni and Echinococcus granulosus) and cross-reactivities in human infections and immunized animals. Acta Trop 89: 73-84.

ITESP-Instituto de Terras do Estado de São Paulo 2004. Resultados/ dados gerais sobre a localização de assentamentos e quantidades de produtores rurais assentados. http:// www.itesp.sp.gov.br, acessed in 18 Dec 2004.

Kobayashi J, Hasegawa H, Forli AA, Nishimura NF, Yamanaka A, Shimabukuro T, Sato Y 1995. Prevalence of intestinal parasitic infection in five farms in Holambra, São Paulo, Brazil. Rev Inst Med Trop São Paulo 37: 13-18.

Laemmli UK 1970. Cleavage of structural proteins during the assembly of the head of bacteriophage T4. Nature 15: 680685.

Lees W, Nightingale J, Brown D, Scandrett B, Gajadhar A 2002. Outbreak of Cysticercus bovis (Taenia saginata) in feedlot cattle in Alberta. Can Vet J 43: 227-228.

Lonardoni MV, Bertolini DA, Silveira TG, Arraes SM, Svidzinski TI, Cardoso RF, Gomes ML, Dias ML, Visentainer JE, Misuta NM, Ramos M, Siqueira VL 1996. Frequency of anti-Cysticercus cellulosae antibodies in individuals from five counties in the Northern region of Brazil. Rev Saúde Pública 30: 273-279.

Pal DK, Carpio A, Sander JW 2000. Neurocysticercosis and epilepsy in developing countries. J Neurol Neurosurg Psychiatry 68: 137-143.

Pardini AX, Peralta RH, Vaz AJ, Machado LR, Peralta JM 2002. Use of Taenia crassiceps cysticercus antigen prepara- 
tions for detection of antibodies in cerebrospinal fluid samples from patients with neurocysticercosis (Taenia solium). Clin Diagn Lab Immunol 9: 190-193.

Pessoa S, Martins AV 1982. Parasitologia Médica, Guanabara Koogam, Rio de Janeiro, 872 pp.

Phiri IK, Ngowi H, Afonso S, Matenga E, Boa M, Mukaratirwa S, Githigia S, Saimo M, Sikasunge C, Maingi N, Lubega GW, Kassuku A, Michael L, Siziya S, Krecek RC, Noormahomed E, Vilhena M, Dorny P, Willingham AL 2003. The emergence of Taenia solium cysticercosis in Eastern and Southern Africa as a serious agricultural problem and public health risk. Acta Trop 87: 13-23.

Raether W, Hanel H 2003. Epidemiology, clinical manifestations and diagnosis of zoonotic cestode infections: an update. Parasitol Res 91: 412-438.

Rodriguez-Sosa M, Saavedra R, Tenorio EP, Rosas LE, Satoskar AR, Terrazas LI 2004. A STAT4-dependent Th1 response is required for resistance to the helminth parasite Taenia crassiceps. Infect Immun 72: 4552-4560.

Sakai H, Barbosa HV Jr, Silva EM, Schlabitz FO, Noronha RP, Nonaka N, Franke CR, Ueno H 2001. Seroprevalence of Taenia solium cysticercosis in pigs in Bahia State, north- eastern Brazil. Am J Trop Med Hyg 64: 268-269.

Silveira-Lacerda EP, Machado ER, Arantes SC, Costa-Cruz JM 2002. Anti-Taenia solium metacestodes antibodies in serum from blood donors from four cities of Triangulo Mineiro area, Minas Gerais, Brazil, 1995. Rev Inst Med Trop São Paulo 44: 229-231.

Short JA, Heiner DC, Hsiao RL, Andersen FL 1990. Immunoglobulin E and G4 antibodies in cysticercosis. J Clin Microbiol 28: 1635-1639.

Tsang VC, Brand JA, Boyer AE 1989. An enzyme-linked immunoelectrotransfer blot assay and glycoprotein antigens for diagnosing human cysticercosis (Taenia solium). J Infect Dis 159: 50-59.

Ungar ML, Germano PM 1992. Prevalence of bovine cysticercosis in the state of São Paulo. Rev Saúde Pública 26: 167172.

Vaz AJ, Hanashiro AS, Chieffi PP, Ferreira AW 1990. Frequency of patients with anti-cysticercus cellulosase blood antibodies in 5 municipalities of the state of São Paulo. Rev Soc Bras Med Trop 23: 97-99.

Williams WJ, Beutler E, Erslev AJ, Lichtman AM 1991. Hematology, Mc Graw-Hill, US, 1882 pp. 